\title{
Carbonate sedimentation and effects of eutrophication observed at the Kališta subaquatic springs in Lake Ohrid (Macedonia)
}

\author{
M. Matter ${ }^{1}$, F. S. Anselmetti ${ }^{1}$, B. Jordanoska ${ }^{2}$, B. Wagner ${ }^{3}$, M. Wessels ${ }^{4}$, and A. Wüest ${ }^{1,5}$ \\ ${ }^{1}$ Eawag, Swiss Federal Institute of Aquatic Science and Technology, Surface Waters - Research and Management, \\ 8600 Dübendorf and 6047 Kastanienbaum, Switzerland \\ ${ }^{2}$ Hydrobiological Institute Ohrid, 6000 Ohrid, Macedonia \\ ${ }^{3}$ University of Cologne, Institute of Geology and Mineralogy, 50674 Cologne, Germany \\ ${ }^{4}$ Institute for Lake Research, 88085 Langenargen, Germany \\ ${ }^{5}$ Institute of Biogeochemistry and Pollutant Dynamics, ETH Zurich, 8092 Zurich, Switzerland
}

Received: 19 May 2010 - Published in Biogeosciences Discuss.: 21 June 2010

Revised: 16 November 2010 - Accepted: 18 November 2010 - Published: 23 November 2010

\begin{abstract}
To date, little is known about the role of spring waters with respect to authigenic carbonate precipitation in a shallow lacustrine setting. Lake Ohrid, located in Southeastern Europe, is a large lake fed to over $50 \%$ by karstic springs of which half enter subaquatically and influence significantly its ecology and species distribution. In order to evaluate how sedimentological processes are influenced by such shallow-water springs, the Kališta subaquatic spring area in the north west of Lake Ohrid was investigated by a sidescan sonar survey and with sediment traps and three transects of gravity short cores. Results indicate that sedimentation in the spring area is dominated by authigenic carbonate precipitation. High sedimentation rates and evidences for bio-induced precipitation processes were observed in the water column and in the sediments. Two distinct stratigraphic units characterize the shallow subsurface, both composed of carbonate silts with high carbonate contents of up to $96 \%$, but differing in color, carbonate content and diatom content. A chronological correlation of the cores by radiocarbon dates and ${ }^{137} \mathrm{Cs}$ activities places the transition between the two stratigraphic units after $\sim 1955 \mathrm{AD}$. At that time, coastal sedimentation changed drastically to significantly darker sediments with higher contents of organic matter and more abundant diatoms. This change coincides with the recent human impact of littoral eutrophication.
\end{abstract}

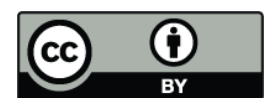

Correspondence to: F. S. Anselmetti (flavio.anselmetti@eawag.ch)

\section{Introduction}

Subaquatic springs are often a substantial source of ionrich waters that may affect authigenic mineral-forming processes in lakes. In particular calcium-rich waters from karstic carbonate-dominated catchments may provide $\mathrm{Ca}^{2+}$ and $\mathrm{HCO}_{3}^{-}$ions to significantly enhance lacustrine carbonate precipitation. With this contribution, we highlight the role of the subaquatic springs in Lake Ohrid for its sedimentbuilding processes and recent sedimentation pattern.

More than for most other lakes, the specific ecology of Lake Ohrid is particularly a mirror of its catchment and its eco-climatological setting and thus likely is strongly dependent on subaquatic springs. Lake Ohrid, shared by Macedonia and Albania (Fig. 1), was probably formed during the Tertiary (Meybeck, 1995). Therefore it is one of the most ancient and long-lived permanent lakes in Europe (Wagner et al., 2008). This long timescale of existence allowed the independent development of an extraordinary ecosystem, characterized by more than 200 endemic species (Stankovic, 1960).

The establishment of this spectacular biodiversity was supported by the subaquatic inflow of cool, clean and oxygenrich water into the lake (Matzinger et al., 2007). Particularly the subaquatic springs seem to have a large potential to support specific habitats for endemic species as they supply oxygen, nutrients, and ions such as calcium at shallow as well as at greater depths. Moreover, they create distinctly different, but constant boundary conditions for the organisms near the springs. Several endemic organisms are found exclusively close to the springs and indicate that the spring water may have been important for the evolution of the unique aquatic

Published by Copernicus Publications on behalf of the European Geosciences Union. 
Table 1. Chemical and physical parameters of Kališta spring waters in April, May and September 2007. The samples were taken at the outlets of surface and subaquatic springs. Barrel, flask and plastic bag indicate different sampling techniques. Lake water samples were taken at different depths above the springs. Saturation indices for carbonate were calculated according to Plummer and Busenberg (1982).

\begin{tabular}{|c|c|c|c|c|c|c|c|c|c|c|}
\hline & $\begin{array}{c}\mathrm{Ca}^{2+} \\
{\left[\mathrm{mg} \mathrm{l}^{-1}\right]}\end{array}$ & $\begin{array}{l}\mathrm{Ca}^{2+} \\
{[\mu \mathrm{M}]}\end{array}$ & $\begin{array}{c}\mathrm{Mg}^{2+} \\
{\left[\mathrm{mg} \mathrm{l}^{-1}\right]}\end{array}$ & $\begin{array}{r}\mathrm{T} \mathrm{P} \\
{\left[\mu \mathrm{g}^{-1}\right]}\end{array}$ & $\begin{array}{r}\text { T N Kjeldahl } \\
{\left[\mathrm{mg} \mathrm{l}^{-1}\right]}\end{array}$ & $\begin{array}{r}\text { Temp. } \\
{\left[{ }^{\circ} \mathrm{C}\right]}\end{array}$ & $\begin{array}{r}\text { Conductivity } \\
{\left[\mu \mathrm{S} \mathrm{cm}^{-1}\right]}\end{array}$ & $\mathrm{pH}$ & $\begin{array}{r}\text { Alk. } \\
{[\mathrm{mval}]}\end{array}$ & $\begin{array}{r}\text { Saturation } \\
\text { index }\end{array}$ \\
\hline \multicolumn{11}{|l|}{3 April 2007} \\
\hline $1 \mathrm{~m}$ water depth & 16.3 & 407 & 7.95 & 3.0 & 347 & 10.0 & 205.2 & 8.4 & 2.28 & 0.28 \\
\hline $7.5 \mathrm{~m}$ water depth & 16.6 & 415 & 7.45 & 95.9 & 605 & 9.5 & 207.0 & 8.4 & 2.24 & 0.28 \\
\hline surface spring & 33.8 & 844 & 3.52 & 14.6 & 448 & 11.7 & 344.0 & 7.2 & 3.58 & -0.37 \\
\hline \multicolumn{11}{|l|}{18 April 2007} \\
\hline $1 \mathrm{~m}$ water depth & 25.5 & 637 & 8.36 & 14.0 & - & 11.9 & 206.3 & 8.3 & 2.80 & 0.50 \\
\hline spring (flask) & 58.7 & 1465 & 4.04 & 30.3 & 448 & 10.6 & 240.0 & 7.9 & 2.76 & 0.44 \\
\hline \multicolumn{11}{|l|}{15 May 2007} \\
\hline $1 \mathrm{~m}$ water depth & 22.5 & 562 & 7.80 & 69.9 & 675 & 19.7 & 206.0 & 8.2 & 2.40 & 0.40 \\
\hline spring (plastic bag) & 35.0 & 874 & 2.370 & 83.0 & 562 & 10.7 & 247.7 & 7.7 & 2.97 & 0.05 \\
\hline surface spring & 47.8 & 1192 & 3.73 & 60.2 & 489 & 11.5 & 333.0 & 7.4 & 4.00 & 0.02 \\
\hline \multicolumn{11}{|l|}{27 Sept. 2007} \\
\hline $1 \mathrm{~m}$ water depth & 33.8 & 842 & 2.23 & 0.7 & 320 & 19.3 & 201.0 & 8.4 & 2.10 & 0.40 \\
\hline spring (flask) & 34.5 & 860 & 3.55 & 2.4 & 630 & $10.7^{\mathrm{a}}$ & 245.0 & 7.6 & 3.00 & 0.12 \\
\hline surface spring & 42.8 & 1066 & 3.71 & 0.7 & 528 & 11.7 & 328.0 & $7.4^{\mathrm{b}}$ & 4.10 & 0.26 \\
\hline
\end{tabular}

a Missing in the original data. This is an average temperature from the subaquatic springs.

$\mathrm{b}$ Missing in the original data. This is an average $\mathrm{pH}$ from the subaquatic springs.

ecosystem of Lake Ohrid (Stankovic, 1960; Matzinger et al., 2006b; Albrecht and Wilke, 2008; Hauffe et al., 2010; Trajanovski et al., 2010). Because the hydraulic through-flow is only weak in Lake Ohrid, with a long water residence time of $\sim 70 \mathrm{yr}$, those subaquatic springs contribute a significant portion of the water budget, as Lake Ohrid is fed to $\sim 54 \%$ by spring waters. The water balance of these springs indicates that half of the spring water enters the lake at its surface, while the other half intrudes subaquatically (Matzinger et al., 2006b). Furthermore, the dilution of regular lake waters with pure spring waters (Matzinger et al., 2006a) is important for the oligotrophic status of Lake Ohrid and its subsequent low algae productivity. However, knowledge on the activity and the hydrological conditions of these springs including their sedimentological environment is very limited or entirely absent. First studies focused on regular analyses of the water chemistry (Table 1) since 2004 so that now information is available on how these waters potentially affect limnologic processes in the lake.

The sediment deposition nearby the subaquatic springs is an interesting archive reflecting the role of those springs. Sediments act as recorders of chemical, physical and biological boundary conditions, so that changes in lake and/or spring waters should be reflected in the sediment composition. Especially, the high $\mathrm{Ca}^{2+}$ and $\mathrm{HCO}_{3}^{-}$content of the spring waters (Table 1) suggest that authigenic calcite precipitation could take place particularly near the springs affect- ing the local sedimentation processes. Previous studies from deep basin sediment cores indicate that carbonate precipitation seems to have been absent or reduced in Lake Ohrid during certain periods of the Holocene, which could have been caused by lower ion concentrations and/or less spring activity (Shapley et al., 2005; Wagner et al., 2009, 2010; Vogel et al., 2010b). As the subsurface of Lake Ohrid is targeted for a deep drilling campaign in the frame of the International Continental Scientific Deep Drilling Program (ICDP; Wagner et al., 2008), knowledge of the sedimentologic role of the springs is needed in order to establish the paleoenvironmental implications of the future deep drill cores.

This study thus aims at characterizing the sedimentation pattern at the Kališta spring area. We address the question, whether the subaquatic springs substantially influence the in-situ carbonate precipitation as it is stored in the sediments. We will investigate, whether spring sedimentation changed through time. One concern is the impact of humaninduced eutrophication since the 1950s due to increasing nutrient input following the growing population and its anthropogenic activity. Due to its large volume and slow response time (Matzinger et al., 2007), Lake Ohrid is still oligotrophic and eutrophication could be delayed. A potential effect on the shallow water realm has never been investigated and the record of the near-spring sediments provides important integrative information. 


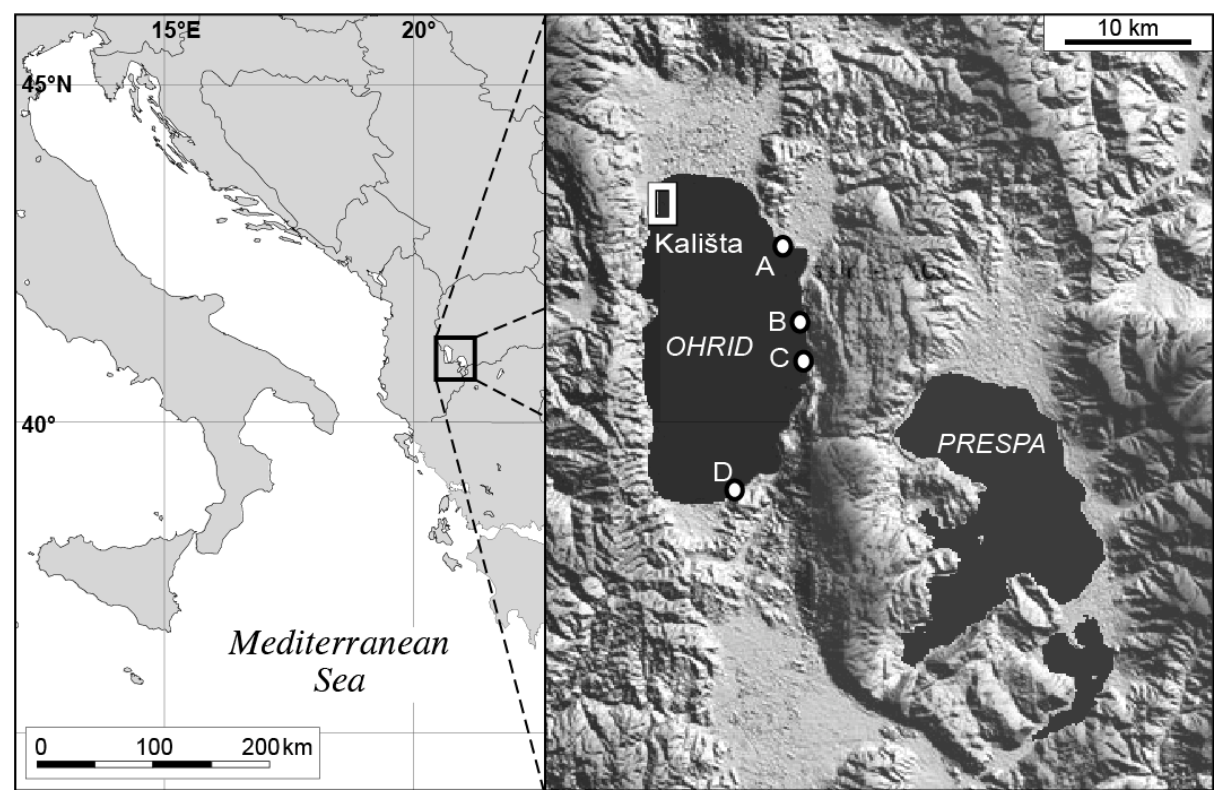

Fig. 1. Location and map of Lakes Ohrid and Prespa with site of the Kališta subaquatic springs in the northwestern corner of Lake Ohrid (white frame). Four white dots indicate locations of the other major subaquatic spring areas; $\mathrm{A}=\mathrm{Kaneo}, \mathrm{B}=\mathrm{Elešec}, \mathrm{C}=\mathrm{Velidab}, \mathrm{D}=\mathrm{Sveti}$ Naum.

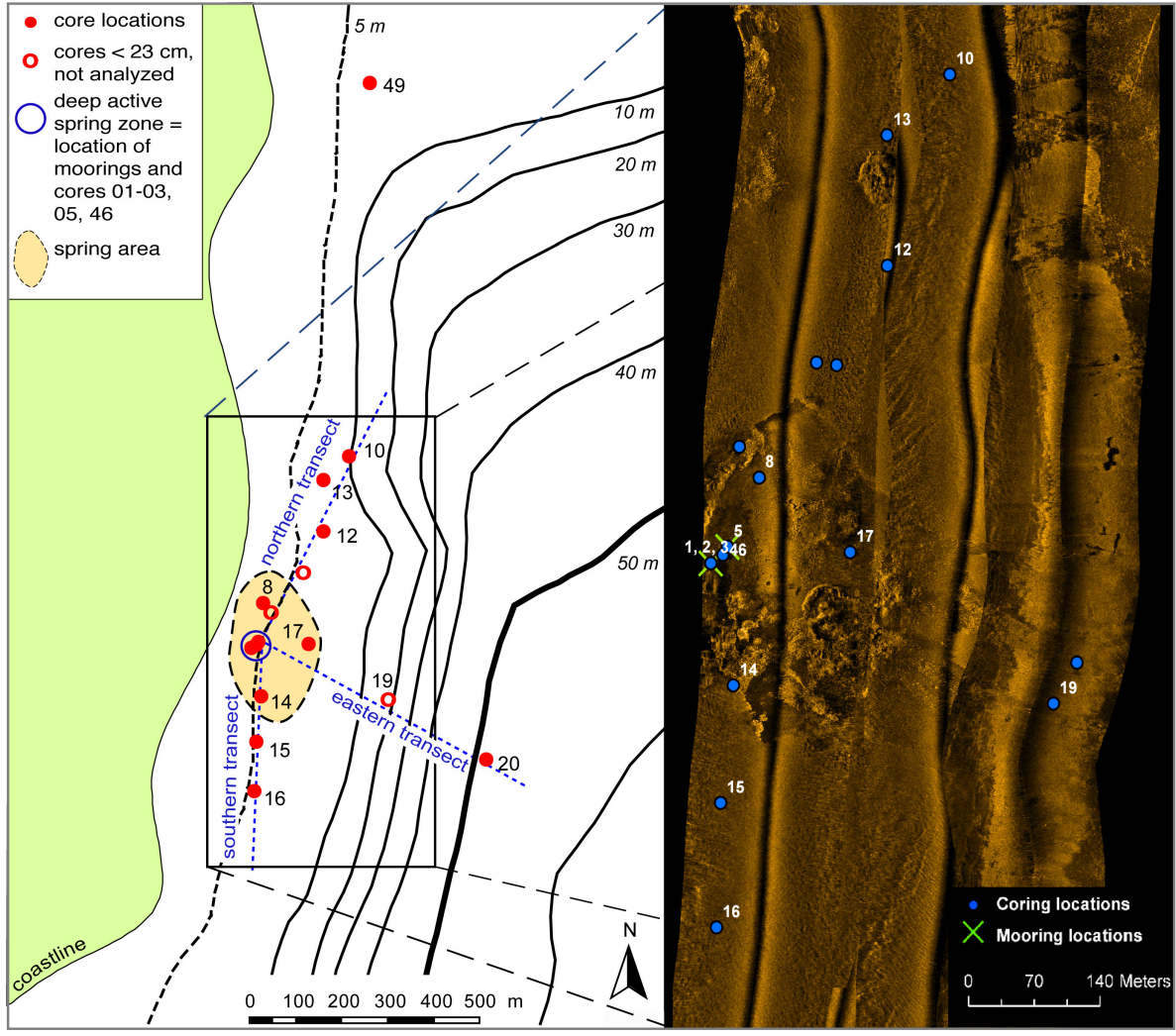

Fig. 2. left: Map of coring transects in the vicinity of the springs with location of main spring area (orange), cores and moorings. Black lines indicate bathymetric contours referring to a lake level of $693 \mathrm{~m}$ a.s.l. Black rectangle coincides with area of detail map shown right. right: Sidescan sonar image of the spring area and surroundings with mooring locations (green crosses) and coring locations (blue dots). The vertical lines mimic the ship tracks and are sidescan artifacts. Note surface roughness in spring area, indicating partly exposed bedrock and macrophyte patches. 
Table 2. Sediment trap analysis: Dry mass, TIC and TOC contents, mass accumulation and sedimentation rates for various depths. The trap numbers refer to moorings 1 and 2 (Fig. 3).

\begin{tabular}{|c|c|c|c|c|c|c|c|}
\hline $\begin{array}{l}\text { Water depth } \\
{[\mathrm{m}]}\end{array}$ & Trap no. & $\begin{array}{l}\text { Fresh } \\
\text { content }\end{array}$ & $\begin{array}{l}\text { Dry mass } \\
{[\mathrm{g}]}\end{array}$ & $\begin{array}{l}\text { TIC } \\
{[\%]}\end{array}$ & $\begin{array}{l}\text { TOC } \\
{[\%]}\end{array}$ & $\begin{array}{l}\text { Accumulation } \\
\text { rate } \\
{\left[\mathrm{g} \mathrm{m}^{-2} \mathrm{~d}^{-1}\right]}\end{array}$ & $\begin{array}{l}\text { Sedimentation } \\
\text { rate } \\
{\left[\mathrm{mm} \mathrm{yr}^{-1}\right]}\end{array}$ \\
\hline 3.6 & $1 \mathrm{a}$ & $\begin{array}{l}<1 \mathrm{~mm} \\
\text { sediment }\end{array}$ & 0.147 & - & - & 0.5 & 0.3 \\
\hline 5.6 & $1 b$ & $\begin{array}{l}2-3 \mathrm{~mm} \\
\text { sediment }\end{array}$ & 0.818 & 8.5 & 6.6 & 2.6 & 1.5 \\
\hline 4.1 & $2 a$ & $\begin{array}{l}<1 \mathrm{~mm} \\
\text { sediment, } \\
\text { many algae }\end{array}$ & 0.107 & - & - & 0.3 & 0.2 \\
\hline 4.9 & $2 b$ & $\begin{array}{l}\sim 1 \mathrm{~mm} \\
\text { sediment, } \\
\text { few algae }\end{array}$ & 0.256 & - & - & 0.8 & 0.5 \\
\hline 5.7 & $2 \mathrm{c}$ & $\begin{array}{l}\sim 1 \mathrm{~mm} \\
\text { sediment, } \\
\text { many algae }\end{array}$ & 0.521 & - & - & 1.6 & 1.0 \\
\hline 6.5 & $2 d$ & $\begin{array}{l}\sim 5 \mathrm{~mm} \\
\text { sediment, } \\
\text { lot of algae }\end{array}$ & 2.34 & 9.9 & 3.4 & 7.4 & 4.3 \\
\hline $7.3^{\mathrm{a}}$ & $2 \mathrm{e}$ & $\begin{array}{l}\sim 1 \mathrm{~cm} \\
\text { sediment, } \\
\text { lot of algae, } \\
1 \text { fish and } 2 \\
\text { leeches }\end{array}$ & 42.7 & 10.4 & 1.4 & 135 & 79.1 \\
\hline
\end{tabular}

a This data is omitted for discussion. The mass accumulation rate of $135 \mathrm{~g} \mathrm{~m}^{-2} \mathrm{~d}^{-1}$ is an artifact: Probably not the entire sediment trapped in $2 \mathrm{e}$ actually sedimented, but part of it was flushed into this trap through turbulence from the surrounding lake floor.

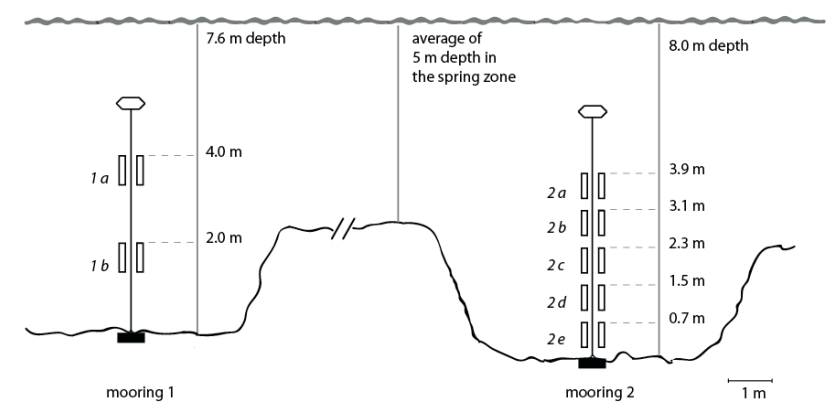

Fig. 3. Schematics of the two moorings with pairs of cylinder sediment traps (with indicated distance from ground) deployed in two local depressions in the spring zone.

\section{Study site}

Lake Ohrid $\left(40^{\circ} 54^{\prime}\right.$ to $41^{\circ} 10^{\prime} \mathrm{N}$ and $20^{\circ} 38^{\prime}$ to $\left.20^{\circ} 48^{\prime} \mathrm{E}\right)$ is situated at $693 \mathrm{~m}$ a.s.l. in a mountainous and partly karstic region. Lake Ohrid is large $\left(358 \mathrm{~km}^{2}\right)$ and deep $(289 \mathrm{~m})$ and is one of the most voluminous $\left(55 \mathrm{~km}^{3}\right)$ lakes in Europe. A particularity of Lake Ohrid is the $\sim 27 \%$ contribution of the subaquatic springs to the overall water input of $\sim 38 \mathrm{~m}^{3} \mathrm{~s}^{-1}$ (Watzin et al., 2002; Matzinger et al., 2007). Together with another $\sim 27 \%$ inflow by surface springs, the karstic springs provide altogether the major part of the Lake Ohrid water input. The karstic aquifers are fed either by infiltrated precipitation or by nearby Lake Prespa (Matzinger et al., 2006a), which is situated $\sim 160 \mathrm{~m}$ higher towards south-east (Fig. 1). There are in total about five known major zones of subaquatic inflows (Fig. 1), as identified and located in Albrecht and Wilke (2008).

In this paper, we focus on the Kališta spring area, situated in the north-western part of the lake (Fig. 1), which is fed by infiltrated atmospheric water. The site's particular lake floor can be observed by eye through the clear waters. The spring area is characterized by water depths of 4 to $6 \mathrm{~m}$, but there are depressions with maximum water depths of $8 \mathrm{~m}$. The most active subaquatic springs are concentrated in a $\sim 8 \mathrm{~m}$ deep depression concentrated in a 40 to $60 \mathrm{~m}$ wide zone located $\sim 100 \mathrm{~m}$ from the shore (Fig. 2). Saturation indices for calcium carbonate (Plummer and Busenberg, 1982) are, 
Table 3. Radiocarbon data and IntCal09 calibrated ages (Bronk Ramsey, 2009; Reimer et al., 2009) for three samples in the vicinity of Kališta spring area.

\begin{tabular}{llllll}
\hline $\begin{array}{l}\text { Core } \\
\text { No. }\end{array}$ & $\begin{array}{l}\text { Depth } \\
{[\mathrm{cm}]}\end{array}$ & $\begin{array}{l}\text { Material } \\
\text { description }\end{array}$ & $\begin{array}{l}\text { Weight } \\
{[\mathrm{mg} \mathrm{C}]}\end{array}$ & $\begin{array}{l}\text { Radiocarbon age } \\
{[\mathrm{yr}]}\end{array}$ & $\begin{array}{l}\text { Calibrated age (2-sigma) } \\
{[\mathrm{yr}]}\end{array}$ \\
\hline 03 & 73 & charcoal & 1.1 & $3290 \pm 35 \mathrm{BP}$ & $3532 \pm 88$ cal. yr BP \\
12 & 21 & charcoal & 6.7 & $3260 \pm 20 \mathrm{BP}$ & $3487 \pm 74$ cal. yr BP \\
13 & 46 & wood & 5.1 & $5555 \pm 25 \mathrm{BP}$ & $6350 \pm 51$ cal. yr BP \\
\hline
\end{tabular}

except for one sample, always positive (Table 1), indicating favorable conditions for calcite precipitation. Observations at these underwater springs show outflowing "bubbling" water with 10 to $30 \mathrm{~cm}$-high white plumes sometimes forming small craters.

\section{Methods}

Two moorings with sediment traps were positioned in depressions identified by echosounder profiles at 7.6 and $8.0 \mathrm{~m}$ water depths within the subaquatic spring zone during two weeks in May 2007 (Figs. 2, 3). Divers tied the moorings to anchors after the disturbed sediment had settled for 10 to $15 \mathrm{~min}$. The sediment traps consisted each of two paired cylindrical open tubes 50 to $70 \mathrm{~cm}$ in length, with an inner diameter of $5.8 \mathrm{~cm}$. Both moorings had two and five traps, respectively, at various water depths (Fig. 2; Table 2). The vertical position of the mooring during the 14-days sampling period was guaranteed by buoys. The protection caps on the two lower sediment traps were removed $10 \mathrm{~min}$ after mooring deployment, when disturbed sediment due to diver's movements had settled, thus preventing an impact on the collected sediment.

After recovery of the sediment traps, organic matter was removed with a $2 \% \mathrm{H}_{2} \mathrm{O}_{2}$ solution for four days, the homogeneous dry material of the sediment traps was weighed, and mass accumulation rates $k\left(\mathrm{~g} \mathrm{~m}^{-2} \mathrm{~d}^{-1}\right)$ of dry material were calculated using:

$k=\frac{m_{\mathrm{dry}}}{a \Delta t}$

where $\mathrm{m}_{\text {dry }}(\mathrm{g})$ is the dry mass collected, a $\left(0.0052 \mathrm{~m}^{2}\right)$ is the open trap area, and $\Delta \mathrm{t}$ the time interval of exposure (14 d).

Twenty gravity cores of up to $82 \mathrm{~cm}$ length were recovered in May 2007 along three transects (Fig. 2). Cores were taken along the shore every $\sim 100 \mathrm{~m}$ starting from the springs towards north and south in water depths of up to $\sim 10 \mathrm{~m}$, as well as towards the center of the lake, reaching a water depth of $\sim 50 \mathrm{~m}$. Additional push cores were recovered in September 2007 by divers within the depression of the active spring zone (core 46) and at a distance of $1250 \mathrm{~m}$ from the spring on the northern transect (core 49; Fig. 2).

Before opening, cores were scanned petrophysically with a Geotek multisensor core-logger (MSCL; wet bulk-density, p-wave velocity, magnetic susceptibility). Then they were opened, photographed and described macroscopically. Total carbon (TC) and total inorganic carbon (TIC) were analyzed using a coulometer (5012 Coulometer, UIC Inc. Coulometrics) measuring the $\mathrm{CO}_{2}$ content derived from beforehand freeze-dried samples by burning (TC) and acidification (TIC). Carbonate contents were calculated based on the assumption that TIC is completely formed by $\mathrm{CaCO}_{3}$. Total organic carbon (TOC) content was calculated as difference between TC and TIC. Grain size was measured through laser diffraction with a Malvern Mastersizer 2000 Particle Analyzer. X-ray fluorescence (XRF) core scanning at $2 \mathrm{~mm}$ resolution with a COX ITRAX core scanner provided a non-destructive and fast way of analyzing the elemental composition of the downcore chemical profiles. Smear slides were prepared from selected depths in the cores and from trap material to analyze with a polarization microscope the composition and crystal morphology. Furthermore, particles were also analyzed with a Scanning Electron Microscope (SEM) including energy-dispersive X-ray spectroscopy (EDX) chemical analysis, in order to investigate mineralogy, morphology and origin of particles.

Chronostratigraphy of the sediment cores was determined on the basis of (i) radiocarbon analysis (measured at the Leibniz Laboratory for Radiometric Dating and Isotope Research in Kiel, Germany; Table 3) on terrestrial organic matter and (ii) using ${ }^{210} \mathrm{~Pb}$ and ${ }^{137} \mathrm{Cs}$ activities measured with Germanium gamma detectors. Radiocarbon data were calibrated using the OxCal4.1 program and the IntCal09 data set (Bronk Ramsey, 2009; Reimer et al., 2009).

In spring 2008, a sidescan sonar survey was carried out covering the larger spring zone with a Klein 3000 dual frequency sidescan sonar operated at frequencies of 100 and $500 \mathrm{kHz}$. Individual transect covered $75 \mathrm{~m}$ at each side, with an overlap of about 50\%. Mosaicking of profiles and target management was done using the software package Sonar Wiz. 


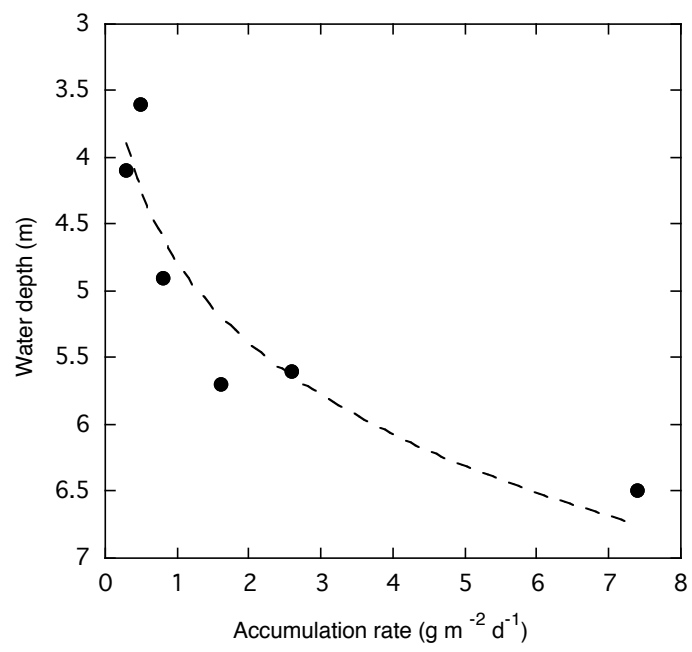

Fig. 4. Mass accumulation rates as a function of water depth of individual traps calculated for the period 15 to 29 May 2007. Dashed line represents best fit for visual guide.

\section{Results}

\subsection{Sediment traps}

The sediment traps were deployed on 15 May and retrieved on 29 May 2007, and covered a period characterized by the absence of strong winds. After retrieval, the inside of the liners and the surface of the trapped sediment were covered by algae, indicating rapid growth. All traps contained cream-colored and flocculent sediment of variable amounts (Table 2).

In the analyzed three trap samples $(1 \mathrm{~b}, 2 \mathrm{~d}, 2 \mathrm{e}$; Table 2 ; Fig. 3), carbonate content varies between 70.5 and $86.4 \%$, and TOC (after $4 \mathrm{~d}$ of $\mathrm{H}_{2} \mathrm{O}_{2}$ treatment for removing algal growth) between 1.4 and $6.6 \%$ (Table 2). The highest mass accumulation rate occurred in the deepest trap of mooring 2 (2e; Table 2) with $135 \mathrm{~g} \mathrm{~m}^{2} \mathrm{~d}^{-1}$. However, as a dead fish and two leeches were collected, this value is falsified. The lowest amount of particles was accumulated in the shallowest trap of mooring 2 (trap 2a) with $0.3 \mathrm{~g} \mathrm{~m}^{2} \mathrm{~d}^{-1}$ (Table 2). In general, our data indicate that particle flux increases with water depth (Fig. 4).

Samples analyzed under the optical microscope in crosspolarized light and with the SEM/EDX allowed the characterization of the particles. Most particles were confirmed to be calcite crystals with different morphologies, ranging from perfect authigenic idiomorphic crystals (Fig. 5a) to corroded crystals or larger irregular clusters (Fig. 5b). The largest observed calcite crystals in the traps reach lengths of up to $20 \mu \mathrm{m}$ (Fig. 5a). Large clusters of idiomorphic calcite crystals in sediment trap material can be up to $150 \mu \mathrm{m}$ long. Prominent $\sim 1 \mu \mathrm{m}$ large holes occur frequently in numerous calcite crystals from the sediment traps (Fig. 5b).

\subsection{Sediment cores}

\subsubsection{Lithologies}

The sidescan sonar image confirmed the large depression forming the more active spring zone, which is separated by sharp edges from the surrounding area (Fig. 2). Inside the depression, dense patches of macrophytes were identified. At some locations directly in the spring area, coring failed due to absence of sediment so that PVC-liners broke upon hitting the exposed bedrock. Upon opening, many cores had a strong sewage smell, in particular from the topmost $5 \mathrm{~cm}$.

The magnetic susceptibility of most cores is rather constant over depth and ranges between 50 and $150 \times 10^{-5}$ (SI units). All cores, except core 20, which originates from a deeper water depth of $53 \mathrm{~m}$ (Fig. 2), are composed only of two main lithostratigraphic (Units $\mathrm{T}$ and $\mathrm{L}$ ) units that are characterized by a distinct change in lithology (Figs. 6, 7, 8 ) but by similar grain size distribution ( $56 \%$ silt on average; mean grain size ranges between 35 and $65 \mu \mathrm{m})$. On the basis of grain composition, grain size, color and geochemical signatures, Matter (2007) subdivided the lithologic succession of the recovered cores in seven and four lithotypes for Units $\mathrm{T}$ and $\mathrm{L}$, respectively. Here, we present the range of lithologies within these units. The top part of the cores (Unit T; “Top"-unit) consists of dark-colored (brown to dark gray) carbonate silt with abundant diatoms frustules, which occur in smear slides of 19 out of 27 analyzed samples. Ostracods $(>120 \mu \mathrm{m})$ and gastropod-shell fragments occur throughout the unit. Dominant grain size is in the silt-range with only few sand layers. Bioturbating chironomid larvae were found in core 05 just above the base of Unit T. No laminations occur and the sediments appear rather homogenous, except for core 05 , which has a diffuse lamination in Unit $\mathrm{T}$. The lower part of the cores comprises Unit L ('Lower' unit), which is composed of brighter-colored (light gray to gray) carbonate silt that shows in smear slides in contrast to Unit $\mathrm{T}$ only minor diatom contents. Ostracods and gastropods occur frequently and sand-sized layers become more abundant. Two particular coarser layers ( $>60$ to $70 \%$ sand) are found at depths around $18 \pm 5 \mathrm{~cm}$ and $33 \pm 5 \mathrm{~cm}$ in most cores, respectively. They are characterized by lower wet bulk density values than in the fine-grained lithologies. Gravel of 0.5 to $2 \mathrm{~cm}$ diameter was found in the lower part of cores $01,02,03$ and 46. Except for these coarser beds, the sediments of Unit L are also rather homogeneous and do not show a significant layering. Within the spring zone, Unit $\mathrm{L}$ gets bright-colored (bright beige to almost white) below 30 to $45 \mathrm{~cm}$ core depth, resembling lacustrine chalk.

Carbonate content varies between 62 to $90 \%$ in Unit T, and is higher in Unit $\mathrm{L}$ with values between 89 and $96 \%$ (Fig. 7), except in few coarser layers, in which carbonate content drops to 63 to $85 \%$. The two units display different contents in organic matter as TOC in Unit L is below 1.4\%, 

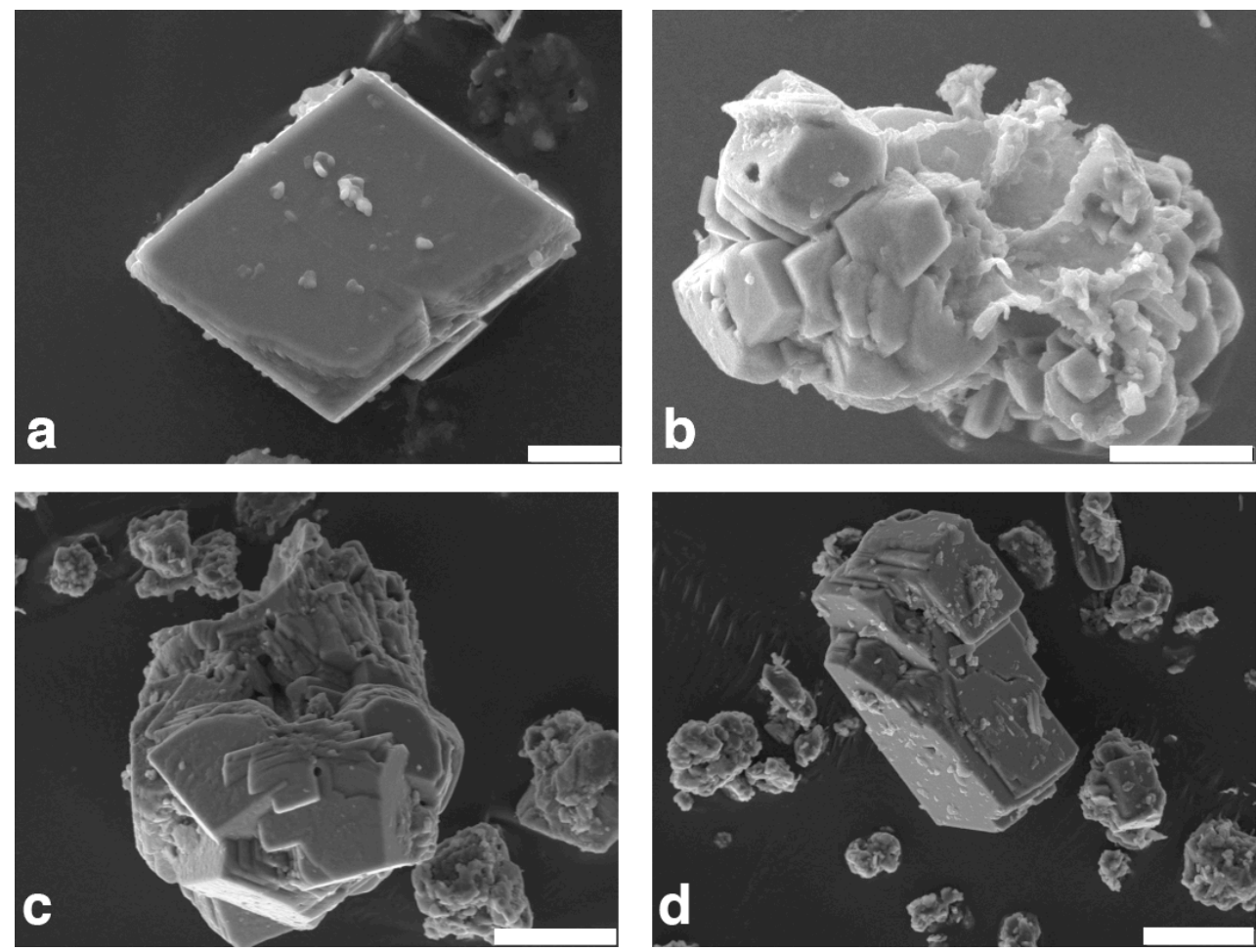

Fig. 5. SEM images from carbonate crystals: (a) authigenic calcite crystals from sediment trap $2 \mathrm{~d}$ (mooring 2 , at $6.5 \mathrm{~m}$ depth; bar length $=5 \mu \mathrm{m}$ ); (b) large idiomorphic calcite crystal clusters from trap $1 \mathrm{~b}$ (mooring 1 , at $5.6 \mathrm{~m}$ depth). Note the hole from cyanobacteriamediated crystallization (bar length $=10 \mu \mathrm{m}$ ); (c) large idiomorphic calcite crystal cluster from core 08 at $15 \mathrm{~cm}$ depth, recovered $\sim 100 \mathrm{~m}$ away from the spring zone (bar length $=20 \mu \mathrm{m}$ ). Note similar holes as in b); (d) large idiomorphic calcite crystal clusters from core 05 at $15 \mathrm{~cm}$ depth recovered in the spring zone (bar length $=20 \mu \mathrm{m}$ ).

whereas Unit T, darker in color, has higher TOC values ranging from 0.3 to $3.5 \%$.

Core 20, taken at $53 \mathrm{~m}$ depth on the eastern transect, resembles basinal cores from other studies (e.g. Matzinger et al., 2007; Wagner et al., 2008; Vogel et al., 2010b). It is composed of a finer grained lithology when compared to the shallow-water cores and furthermore does not show the two lithostratigraphic units as described for the shallow-water cores. Its lithology is characterized by a lower range in carbonate content ( 9 to 67\%) and TOC values between 1 and $2 \%$. Color ranges from dark beige to dark grey and black diffuse laminations occur. The fine lithology is dominated by a silty grain-size contributing on average $87 \%$ of the sediment with an average range between 15 and $30 \mu \mathrm{m}$.

\subsubsection{Geochemical signatures}

XRF data provide downcore elemental chemical signatures, of which $\mathrm{Ca}, \mathrm{Fe}$ and $\mathrm{Si}$ are shown in Fig. 7, as their profiles show prominent changes in sediment composition and properties. The Ca profile is clearly correlated to the measured carbonate content. As dolomite is not formed under these in situ conditions, calcite forms the dominant sediment component, which was also confirmed in SEM images. Ca counts usually are lower in Unit $\mathrm{T}$ compared to Unit $\mathrm{L}$, coinciding with the lower carbonate content in the upper Unit. The Si and $\mathrm{Fe}$ curves correlate among each other and anticorrelate with $\mathrm{Ca}$. They both show a significant upcore increase at the Unit L-Unit $\mathrm{T}$ boundary. This increase towards higher $\mathrm{Fe}$ and $\mathrm{Si}$ values in Unit $\mathrm{T}$ is rather sharp and coincides with the change towards darker color with the exception of core 12 , where the change occurs below the boundary.

\subsubsection{Calcite particles}

Idiomorphic calcite crystals and their clusters vary in length between 20 and $100 \mu \mathrm{m}$ (Fig. 5c, d). As in trap samples, many $\sim 1 \mu \mathrm{m}$ large holes occur in the calcite crystals (Fig. 5c). They are very often covered by an organic coating. Large clusters were found in most samples from Unit $\mathrm{T}$, but are very rare and smaller in Unit L samples. In core 20, the deep water core, the idiomorphic crystals are smaller than $20 \mu \mathrm{m}$. In most samples from Unit T, 20 to $100 \mu \mathrm{m}$ large calcite crystals with irregular edges were found, most probably particles that were transported by downslope currents. Indications for such downslope transport processes were also found on sidescan sonar images. This kind of calcite crystal was very rare in Unit L samples of the spring-zone cores but occurred frequently in the spring-distal cores at the edges of the transect. 

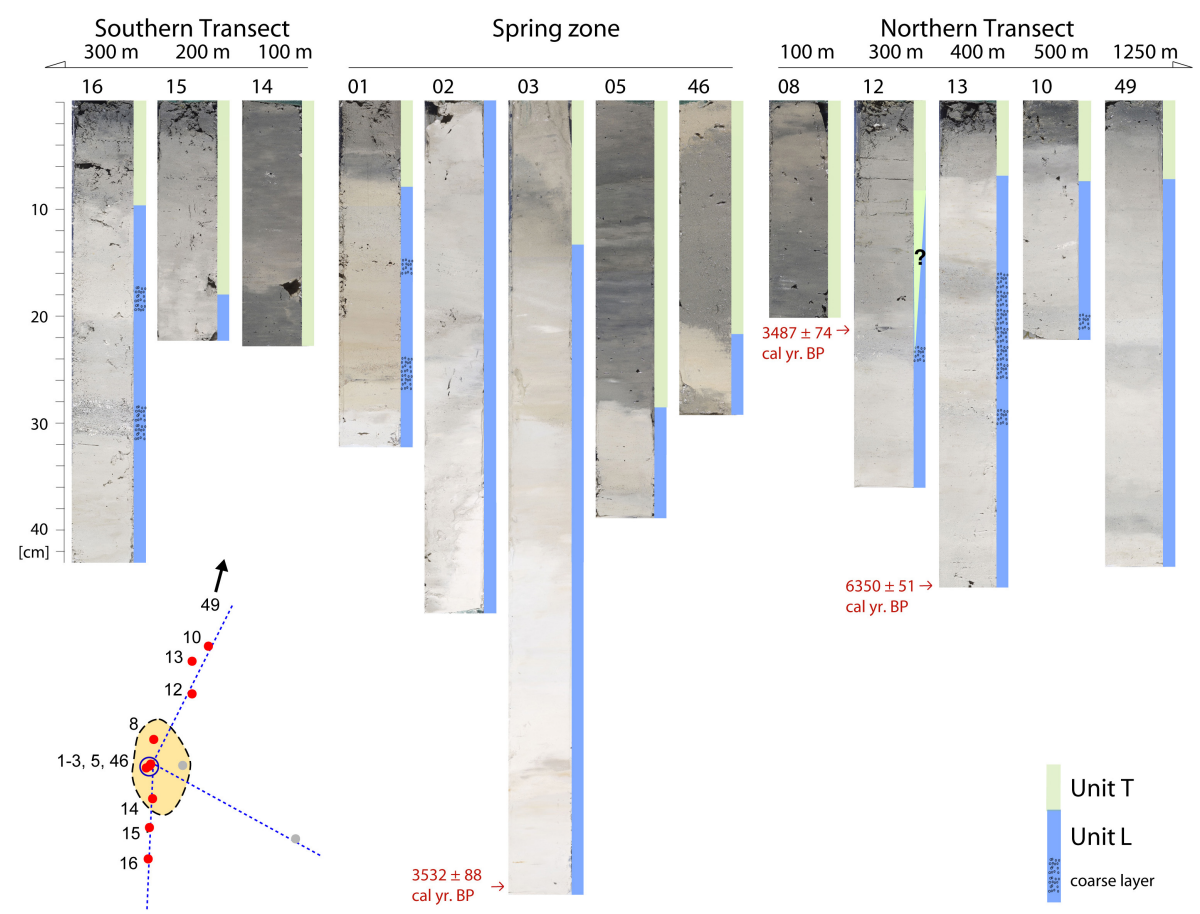

Fig. 6. Photographs of the cores from the northern and southern transects, as well as the subaquatic spring zone (middle). For location see corresponding core number in Fig. 2. Color bars to the right of core photographs indicate lithologic units T (green) and L (blue). Insert map shows location of displayed cores with red dots along the three transects (Fig. 2). Core photographs of the cores from the eastern transect are shown in Fig. 7.

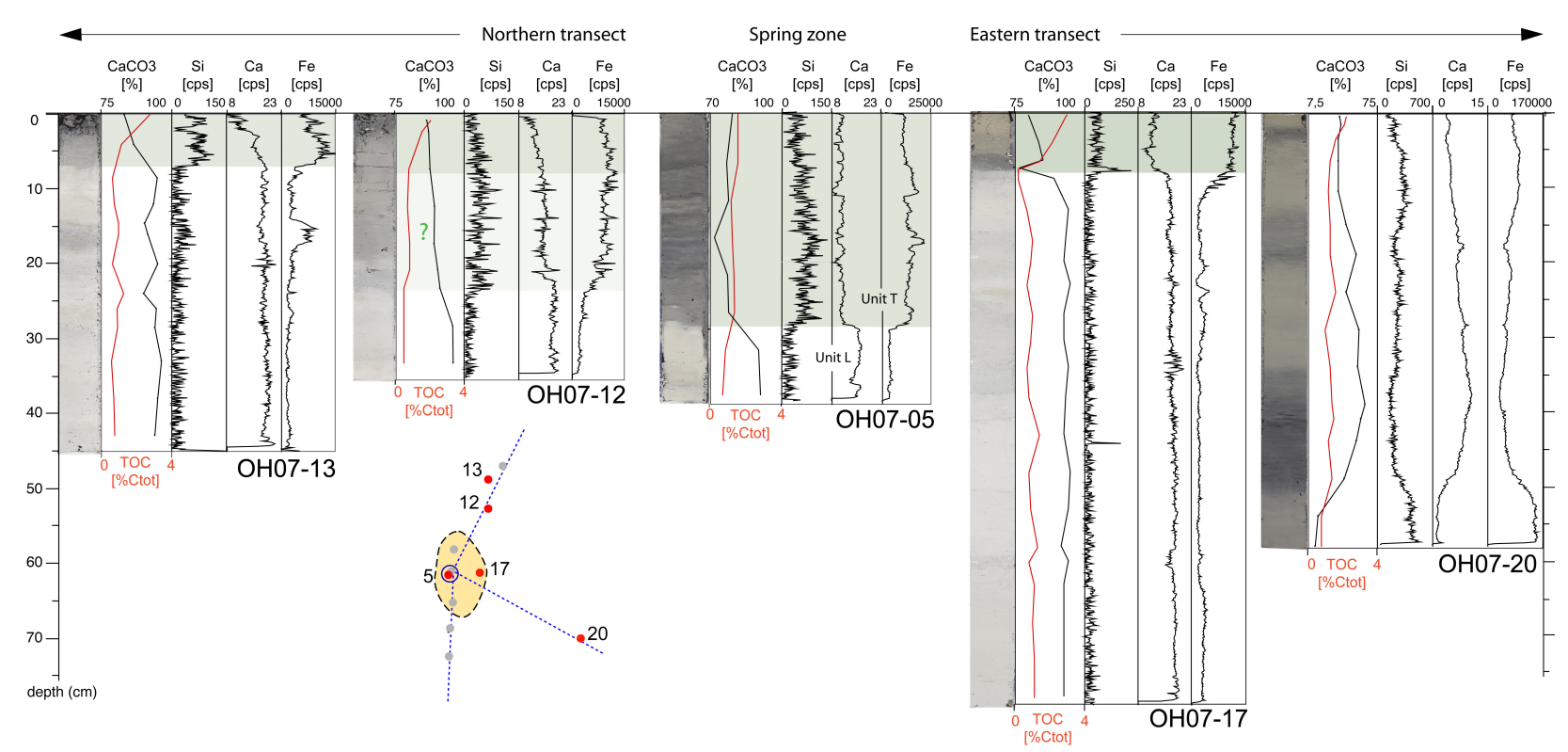

Fig. 7. Geochemical profiles (carbonate content, total organic carbon (TOC), XRF-counts of Si, Ca, and Fe) of cores $13,12,05,17$ and 20 together with core photographs. Green shades indicate Unit T. Note geochemical changes across Unit L-Unit T boundary. Unit assignment in core 12 is not straightforward as indicated by a question mark. Insert map shows location of displayed cores with red dots along the three transects (Fig. 2). 


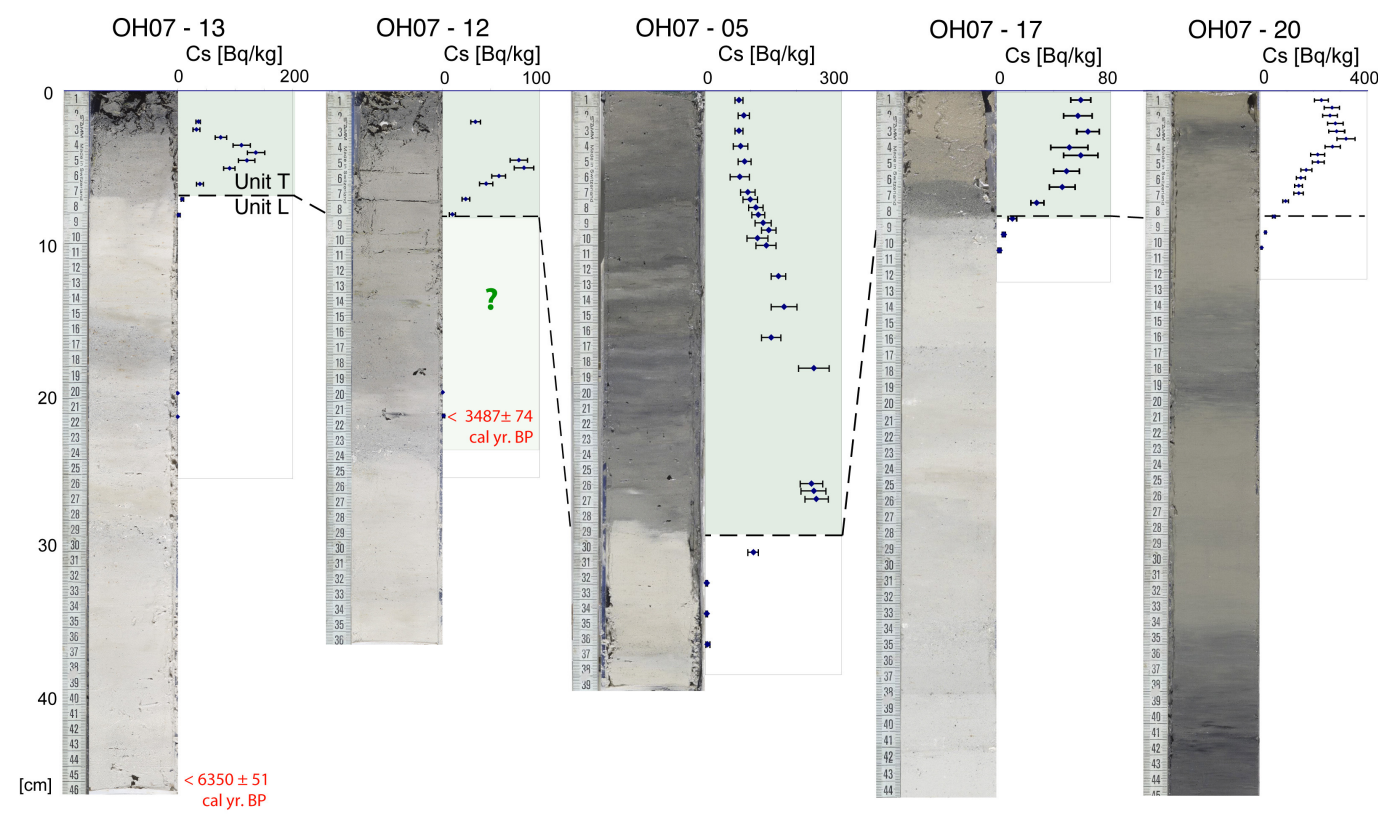

Fig. 8. Photographs and ${ }^{137} \mathrm{Cs}$ activities of selected cores. Green shade indicates Unit T. Note the absence of ${ }^{137} \mathrm{Cs}$ just below the Unit L-Unit $\mathrm{T}$ boundary. Red numbers indicate radiocarbon ages (Table 3). Unit assignment in core 12 is not straightforward as indicated by a question mark.

\subsubsection{Core correlations}

The lithologies of the cores can be correlated along the various transects (Figs. 6, 7). Cores 15 and 16 (in the South) as well as cores 10,12,13, and 49 (in the North) are from locations in shallow water that are more than $200 \mathrm{~m}$ away from the spring zone; they all show similar downcore sequence with a thin Unit $\mathrm{T}$ and an underlying Unit $\mathrm{L}$ containing mostly two coarse layers (Fig. 6).

Cores 08 and 14, taken at $100 \mathrm{~m}$ distance from the spring area, are somehow transitional between the more distal cores and the core from the spring zone (Fig. 6; Unit L was not reached in those cores). They have in the uppermost parts a similar lithology as the cores from within the spring area, but their lower part of Unit $\mathrm{T}$ differs from both the spring zone cores and the other more distant cores as it is coarser and with a lower carbonate content.

Cores 17 and 20 represent the eastern transect towards the lake center and greater water depths. Their lithologies show major changes compared to all shallow-water cores. In the eastern transect, Units $\mathrm{L}$ and $\mathrm{T}$ can only be defined to core 17 (Fig. 7). Core 20 from a water depth of $50 \mathrm{~m}$ shows no clear boundary, however, the TOC curve also indicates an upcore transition to organic-rich lithologies (Fig. 7). The cores within the spring zone (cores 01, 02, 03, 05, 46) show the general pattern of the two lithologic units. Unit $\mathrm{T}$ can be much thicker than outside the spring zone (Fig. 6), but lithologies are more irregular and thickness variations among the cores are larger when compared to the cores outside the zone that show a more regular succession.

\subsection{Age control of the cores}

${ }^{137} \mathrm{Cs}$ activities were measured partly at $5 \mathrm{~mm}$ intervals in the upper parts of five cores $(05,12,13,17$ and 20). The measured downcore curves (Fig. 8) do not display clearly the two expected peaks in radionuclide activity, which would correspond to the climax in atmospheric nuclear bomb testing in AD 1963 and the Chernobyl accident in AD 1986 (Appleby, 2001). However, a clear downcore drop in ${ }^{137}$ Cs values to basically zero occurs systematically at the Unit L-Unit $\mathrm{T}$ boundary, indicating that the maximum age of this boundary coincides with the onset of nuclear bomb testing in the $1955 \mathrm{~s}$ (Appleby, 2001). The absence of two successive pulses in ${ }^{137} \mathrm{Cs}$ activity can be a function of bioturbation and/or current and storm actions that prevent the shallow-water sedimentary succession to represent a continuous period. ${ }^{210} \mathrm{~Pb}$ values varied significantly, lacking clear downcore trends, so that they were not used to modify the age models.

Three organic macro remains of terrestrial origin from three different cores were used for radiocarbon analysis (Table 3, Fig. 6). Resulting calibrated ages (2-sigma) range from $3487 \pm 74$ cal. yr BP at $21 \mathrm{~cm}$ in core 12 , to $3532 \pm$ $88 \mathrm{cal} . \mathrm{yrBP}$ at $73 \mathrm{~cm}$ depth in core 03 , and to $6350 \pm$ $51 \mathrm{cal}$. yr BP at $46 \mathrm{~cm}$ in core 13 . These ages, all taken within Unit L, indicate either reworking of particles in Unit L sediments, or a very dynamic sedimentary environment with transport/erosion phases also in the pre-1955's section. These are probably caused by currents and/or storm activity, which both are very likely to occur for the shallow-water zone in Lake Ohrid. 
The Unit L-Unit $\mathrm{T}$ boundary marks thus a chronostratigraphic sequence boundary separating pre-1955 AD sediments (Unit L) from post-1955 AD sediments (Unit T). Within both units, however, we expect incomplete stratigraphy as neither the ${ }^{137} \mathrm{Cs}$ and ${ }^{210} \mathrm{~Pb}$ profiles, nor the 'old' radiocarbon ages indicate regular and conformable sedimentation so that both units cannot be stratigraphically subdivided.

\section{Discussion}

\subsection{Carbonate precipitation in Kališta spring area}

Seasonal biologically induced calcite precipitation is a common effect in low to mid-latitudes and has already been observed in the deep basin of Lake Ohrid with a previous sediment-trap study (Matzinger et al., 2006b), which established that carbonate precipitation occurs mostly during summer. Our study documents that sediment trap material from the coastal zones is characterized by higher TIC values (between 8.5 and $10.4 \%$ ) compared to those measured in the deep water in the open basin (mean value of $7.8 \%$ in summer period at $50 \mathrm{~m}$ water depth; Matzinger et al., 2006). These patterns are supported by (i) higher $\mathrm{Ca}_{2}{ }^{+}$ion contents in the shallow water spring zone $\left(21-34 \mathrm{mg}^{-1}\right)$ when compared to the averaged lake-wide values $\left(13 \mathrm{mg}^{-1}\right)$ and also by (ii) lower sedimentation rates in the deep basin $\left(\sim 0.9 \mathrm{~mm} \mathrm{yr}^{-1}\right.$ Matzinger et al 2006b). Assuming that no or only little carbonate dissolution occurred during the Holocene in the water column in deeper water, unlike during the Glacial epoch (Vogel et al., 2010b), the sediments deposited in the shallow Kališta site are less affected by dilution from the noncarbonate fraction, i.e. from siliciclastic constituents or from diatoms. Furthermore, the large and characteristic idiomorphic calcite crystals and their clusters observed on SEM images (Fig. 5) confirmed the efficiency of authigenic carbonate precipitation in the spring area and indicate that carbonate dissolution is negligible at least for the period recovered. Water analysis show (Table 1) that the Kališta spring water are richer in dissolved ions and in nutrients than the waters in the central lake, so that enhanced precipitation of $\mathrm{CaCO}_{3}$ due to photosynthetic activities of microorganisms and algae is likely. However, the constant cold water of the springs (colder than lake surface water in summer) might attenuate to some extent the precipitation of $\mathrm{CaCO}_{3}$.

An indication of biological enhancements in calcite precipitation are the regular $\sim 1 \mu \mathrm{m}$ diameter holes that are observed in SEM images of the collected calcite crystals (Fig. 5b, c). Similar holes were identified as being related to the effect of picocyanobacteria (Dittrich et al., 2004). According to studies conducted in oligotrophic lakes (Dittrich et al., 2004; Dittrich and Obst, 2004), picocyanobacteria (or picoplankton) with cell size of 0.2 to $2 \mu \mathrm{m}$ act as nuclei for the formation of calcite crystals. The crystals nucleate and grow around organic matrices reaching out from the cell membrane. Eventually, holes are left when the organisms dissolve. This assumption is supported by the fluorescence microscope analysis of a water sample collected on 29 September 2007 at $1 \mathrm{~m}$ water depth over the spring zone, which resulted in an average concentration of $824 \times 10^{3}$ picocyanobacteria cells $\mathrm{ml}^{-1}$. This cell count is very high, as for a comparison only $\sim 100$ to $300 \times 10^{3}$ cells ml ${ }^{-1}$ were counted in the epilimnion of Lake Lucerne during August and September, respectively (Dittrich et al., 2004). Similar holes in calcite crystals were also observed in authigenic precipitates of a Lake Ohrid core from the deep basin (core Lz1084; Wagner et al., 2008) as shown by SEM images of bulk sediment, indicating similar processes also occurring in the open water even though at lower intensities.

The presence and shape of large authigenic particles in most samples from Unit $\mathrm{T}$ suggest that the particles are deposited in the sediment without major dissolution. The frequent occurrence of calcite particles with irregular edges also documents that some transport occurs in the shallow-water area, for instance during storms. These particles are however less frequent or absent in Unit L from the spring-area cores, suggesting that immediate authigenic calcite precipitation is in the active spring area more significant than reworking and redistribution of previously precipitated crystals.

\subsection{Comparison with basinal cores and extent of the spring's influence}

Assuming an age of post 1955 AD for all Unit L-Unit T transitions encountered in the cores, allows to compare relative sedimentation rates for Unit $\mathrm{T}$ along the transects (Figs. 2, 6). It has however to be considered, that the unit boundary does not necessarily represent a fixed time (e.g. 1955) but is rather a dynamic boundary that is influenced by reworking processes. As the area lies in the range of the wave base for most extreme storm events, sediment reworking by waves and long-scale shore currents must be considered for both lithostratigraphic units. Consequently, sedimentation within Unit $\mathrm{T}$ likely reflects the interplay between particle deposition (i.e. production through authigenic precipitation) and particle removal, as the depositional environment is shallow and highly dynamic.

Comparing the thickness of Unit $\mathrm{T}$ reveals large variations in between the cores from the spring, the littoral zone, and the deeper water (Figs. 6, 8). In the spring zone, thickness of Unit $\mathrm{T}$ amounts to more than $10 \mathrm{~cm}$ and reaches its maximum with $28 \mathrm{~cm}$ in core 05 . Only core 02 is characterized by the absence of Unit $\mathrm{T}$ sediments, which could be caused by an extreme proximity to an active spring outlet that physically prevents sedimentation through strong currents. In a distance more than $300 \mathrm{~m}$ away from the springs and also towards deeper water, Unit $T$ is always thinner than $10 \mathrm{~cm}$ (Figs. 6, 7), reflecting the increased sedimentation rate in vicinity to the springs. All these values document significantly enhanced apparent sedimentation rates in the active spring area, also 


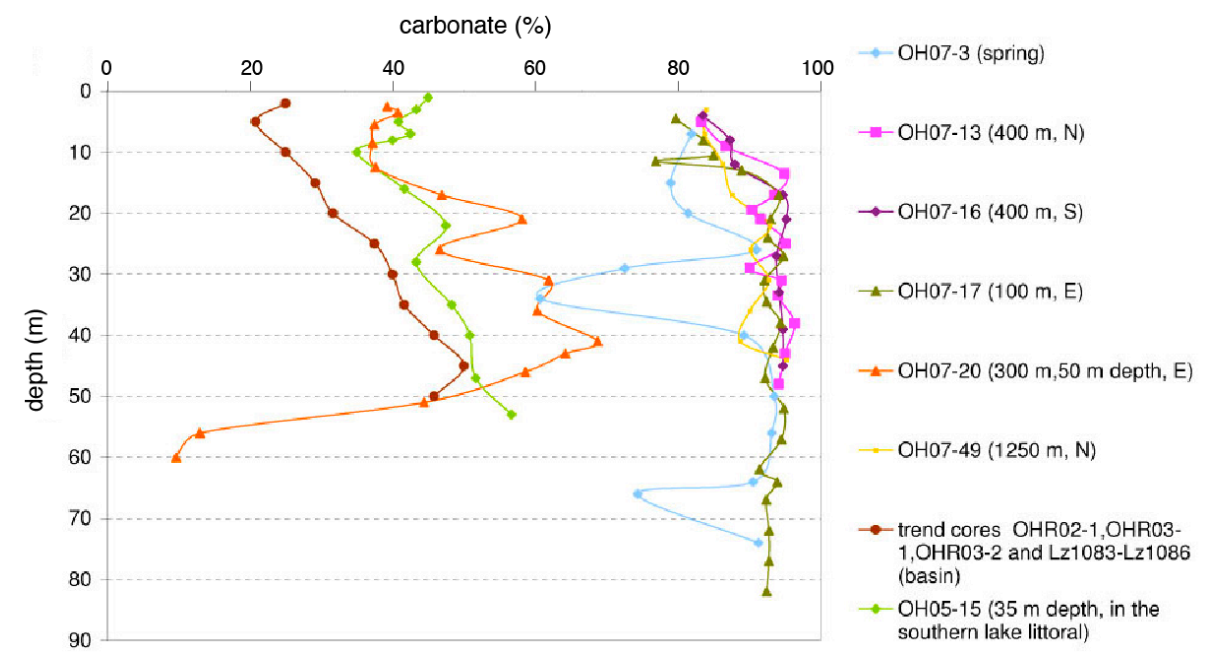

Fig. 9. Comparison of downcore profiles of carbonate \% (as TIC values) of the littoral cores 03, 13, 16, 17, 20, 49 from this study with data from basinal cores (OHR02-1, OHR03-1, OHR03-2 and Lz1083 to Lz1086; Matzinger et al., 2006a) and of core OH05-15 recovered in $35 \mathrm{~m}$ water depth in the southern littoral basin, at $\sim 1 \mathrm{~km}$ distance from the shore. The two minima of core OH07-03 correspond to coarser sediment lithologies. Note the general trend of upcore decreasing carbonate values in most cores independent on their water depth.

when compared to deeper water areas but also when compared to other non-spring shallow water zones. Even if no absolute sedimentation rates should be calculated, due to the non-continuous episodic nature of deposition, the clear trend with thicker Unit $\mathrm{T}$ sediments in the spring zone points towards proximity of an active particle source, i.e. spring-water enhanced carbonate authigenesis.

Figure 9 compares the \% carbonate downcore trends in a series of cores, including those from this study and those from Matzinger et al. (2006b), which were collected in the deeper basin and towards the southern shore. It can be recognized that the carbonate content in the four cores within or close to the active spring zone is 2 to 5 -times higher than the values in basinal cores. Core 20, from the eastern transect forms the transition between the shallow water spring signature and the basinal carbonate contents. The pattern observed in core 20 matches well the general pattern of basinal cores, i.e. that, unlike in the shallow-water cores, now sharp lithologic change can be observed (Matzinger et al., 2006b). Two effects may explain the lower carbonate content in the basin: the first effect is the proximity to the shore, as surface water temperature and higher biologic activity favor carbonate precipitation. The second effect is the mineral-rich water input from sub-aquatic and littoral springs. Although no quantitative discharge values are available, the relatively large area with numerous sub-aquatic springs is likely to have an effect on local water chemistry.

The carbonate-increasing effects of the $\mathrm{Ca}^{2+}$ and $\mathrm{HCO}_{3}^{-}$rich spring waters seems, however, to be rather local, as a lake wide sediment surface survey in Lake Ohrid shows a general trend towards higher TIC values in the northern, northeastern, and southwestern parts of the lake basin coin- ciding with areas with enhanced productivity (Vogel et al., 2010a). This study also documents the difference in carbonate content of the surface sediments in the vicinity of river inflows with high and low $\mathrm{Ca}^{2+}$ and $\mathrm{HCO}_{3}^{-}$contents from carbonate or non-carbonate catchments, resulting in strong or weak rates of carbonate precipitation, respectively (Vogel et al, 2010a).

The similarity in carbonate signatures of core $20(50 \mathrm{~m}$ water depth in front of springs) and core OH05-15 (35 m depth in the southern basin lacking any spring influence) indicates that the springs have hardly any direct influence on the sedimentation at greater water depths. This can be explained by the existence of counter-clockwise surface currents, which apparently transport local influxes mainly parallel to the shore (Vogel et al., 2010a). The gradual reduction in thickness of Unit $\mathrm{T}$ sediments at larger distances from the springs is likely an indication for such a greater springinfluence on sedimentation along the northern and the southern transects. Part of the increased thickness of Unit $T$ in the spring area, however, may also be caused by the bathymetric depression of the main spring zone offering more accomodation space. However, elevated thicknesses are also detectable in the entire spring area, which is not characterized by greater water depths when compared to the spring-distant coring sites where Unit $\mathrm{T}$ is thinnest.

\subsection{Paleoenvironmental history}

The transition from Unit L to Unit $\mathrm{T}$ observed in all cores, except core 20, is an indicator for major change in sedimentary conditions that likely occurred after AD 1955. This change is expressed with a darker sediment color, an increase in TOC, 
a slight decrease in carbonate, an increase in Fe and Si content as well as in diatom content, and a sewage smell upon core opening. The lower carbonate content in the few coarse layers in Unit L is interpreted as a supply also from noncarbonate detrital material, that originates from strong runoff events. The prominent lithologic change across the Unit TUnit L boundary is likely in concert with a significant upcore increase of anthropogenically-induced nutrients that affect the sedimentary conditions, as it has been observed in sediment cores of many eutrophied lakes. In particular TOC is an indicator for elevated productivity, which is also confirmed by sudden appearance of large amounts of diatoms in Unit $\mathrm{T}$ sediments and by concurrent elevated $\mathrm{Si}$ counts. The rotten smell of Unit $\mathrm{T}$ sediments also matches water samples in the Kališta spring zone during 2006 and 2007 that indicated high values of $E$. coli and phosphomineralizing bacteria, which are indicators for anthropogenic waste waters entering the lake. In fact, expanding touristic activities in the area during the last decades and the construction of various lakefront resorts increased the potential of pollution through untreated waters (pers. comm. Lence Lokoska, HBI). The general increase in $\mathrm{Fe}$ in Unit $\mathrm{T}$ is difficult to interpret as $\mathrm{Fe}$ is in Lake Ohrid not only of terrigeneous but also of diagenetic origin, as concretions may occur, in particular in lithologies with high TOC (Wagner et al., 2010; Vogel et al., 2010a).

The general upcore decrease in carbonate content is not only observed in the cores from this study, but can also be seen in the cores from the basin and the southern shore (Matzinger et al., 2006b), which show also a similar pattern of reduced carbonate values towards the core top (Fig. 9). These patterns indicate a lake wide change in sedimentation patterns related to the same forcing mechanisms.

To which degree sedimentation processes have been influenced by a lake level regulation in 1962 (Popovska and Bonacci, 2007) remains unclear. At that time, the River Sateska, previously a direct tributary of the River Crn Drim, was deviated into Lake Ohrid and a gate on the outflow River Crn Drim was constructed in Struga (Popovska and Bonacci, 2007). This increased the lake inflow by $5.5 \mathrm{~m}^{3} \mathrm{~s}^{-1}(\sim 70 \%)$, however, the resulting nutrient and sediment contributions is considered to be small (Matzinger et al., 2007) and most likely not directly responsible for the observed eutrophication.

\section{Conclusions}

This study investigates and quantifies the effect of the Kališta subaquatic springs on coastal sedimentation in Lake Ohrid. The high accumulation rates of $\mathrm{CaCO}_{3}$ within the spring zone and the large idiomorphic calcite crystals and clusters found in the sediment trap material and cores indicate that the ion-rich spring water entering the lake water at the Kališta subaquatic springs significantly enhances local carbonate precipitation. These springs provide special crystal- lization conditions in the spring area so that sedimentation rates are higher in the vicinity of the springs. Picocyanobacteria are assumed to play a crucial role in the crystallization process, as typical holes were found in the crystals and high cell concentrations were observed in the water above the springs. The different morphologies of the carbonate particles analyzed at different depths in the cores offered further clues to identify the origin of the calcite. The amount and size of authigenic calcite crystals found in cores within 200 to $300 \mathrm{~m}$ north and south (shore parallel) to the spring area showed the possible extent of the spring's waters influence.

Two distinct lithostratigraphic units revealed a drastic change in coastal sedimentation that occurred after $A D \sim 1955$. The increase of anthropogenic nutrient input might explain the enhanced biomass production as witnessed by an increased diatom content and elevated Si counts as well as by slightly reduced (diluted) carbonate contents, dark color and sewage smell of the freshly-opened cores. Even though similar changes also occur in deeper waters, Lake Ohrid might show a faster and more drastic response to eutrophication and human impact in its shallow waters.

Acknowledgements. This work was possible thanks to the longterm cooperation between the Hydrobiological Institute in Ohrid (HBI) and Eawag (Swiss Federal Institute of Aquatic Science and Technology). The project was supported through the Swiss National Science Foundation SCOPES-Grant IB7320-111082 (Subaquatic springs in ancient Lake Ohrid - assessment of ecological importance and anthropogenic change). Additional finances were provided by Eawag and ISF (Institute for Lake Research) and the German Research Foundation (WA 2109/1). We would like to thank Zoran Brdakowski, Borce Cakalovski, Dusica Ilic-Boeva, Goce Kostoski, and Zoran Spirkovski for logistic and administrative support. We thank Maria Dittrich for her help in the determination of the picocyanobacteria, Beat Müller for calculating saturation indices, Brian Sinnet for analyzing the calcite clusters under the SEM, Alois Zwyssig, Irene Brunner and Ruth Stierli for their support in the laboratory and Erwin Grieder for radionuclide measurements. Manuel Kunz and Andreas Matzinger are acknowledged for providing data and background information on Lake Ohrid and its springs.

Edited by: T. Wilke

\section{References}

Albrecht, C. and Wilke, T.: Ancient Lake Ohrid: biodiversity and evolution, Hydrobiologia, 615, 103-140, 2008.

Appleby, P. G.: Chronostratigraphic techniques in recent sediments, in: Last W. M, Smol, J. P., Tracking Environmental Change Using Lake Sediments, 1, Kluwer Academic Publishers, Dordrecht, The Netherlands, 171-201, 2001.

Belmecheri, S., Namiotko, T., Robert, C., von Grafenstein, U., and Danielopol, D. L.: Climate controlled ostracod preservation in Lake Ohrid (Albania, Macedonia), Palaeogeogr. Palaeocl., 277, 236-245, 2009. 
Bono, P., Dreybrodt, W., Ercole, S., Percopo, C., and Vosbeck, K.: Inorganic calcite precipitation in Tatare karstic springs (Lazio, Central Italy): Field measurements and theoretical prediction on depositional rates, Environ. Geol., 41, 305-313, 2001.

Bronk Ramsey, C.: Bayesian analysis of radiocarbon dates, Radiocarbon, 51(1), 337-360, 2009.

Cullaj, A., Hasko, A., Miho, A., Schanz, F., Brandl, H., and Bachofen, R.: The quality of Albanian natural waters and the human impact, Environ. Int., 31, 133-146, 2005.

Dittrich, M., Kurz, P., and Wehrli, B.: The role of autotrophic picocyanobacteria in calcite precipitation in an oligotrophic Lake, Geomicrobiol. J., 21, 45-53, 2004.

Dittrich, M. and Obst, M.: Are picoplankton responsible for calcite precipitation in lakes?, Ambio, 33, 559-564, 2004.

Hauffe, T., Albrecht, C., Schreiber, K., Birkhofer, K., Trajanovski, S., and Wilke, T.: Spatially explicit analyses of gastropod biodiversity in ancient Lake Ohrid, Biogeosciences Discuss., 7, 49534985, doi:10.5194/bgd-7-4953-2010, 2010.

Kunz, M.: Karst Springs of Lake Ohrid, Diploma thesis, Swiss Federal Institute of Technology (ETH) Zürich, Switzerland, 67 pp., 2006.

Matter, M.: Subaquatic Springs and Carbonate Precipitation in Lake Ohrid, Master thesis, Swiss Federal Institute of Technology (ETH) Zurich, Switzerland, 2007.

Matzinger, A., Jordanoski, M., Veljanoska-Sarafiloska, E., Sturm, M., Müller, B., and Wüest, A.: Is Lake Prespa jeopardizing the ecosystem of ancient Lake Ohrid?, Hydrobiologia, 553, 89-109, 2006a.

Matzinger, A., Schmid, M., Veljanoska-Sarafiloska, E., Patceva, S., Guseska, D., Wagner, B., Müller, B., Sturm, M., and Wüest, A.: Eutrophication of ancient Lake Ohrid: Global warming amplifies detrimental effects of increased nutrient inputs, Limnol. Oceanogr., 52 (1), 338-353, 2007.

Matzinger, A., Spirkovski, Z., Patceva, S., and Wüest, A.: Sensitivity of ancient Lake Ohrid to local anthropogenic impacts and global warming, J. Great Lakes Res., 32(1), 158-179, 2006 b.

Noges, P., Kangur, K., Noges, T., Reinart, A., Simola, H., and Viljanen, M.: Highlights of large lake research and management in Europe, Hydrobiologia, 599, 259-276, 2008.

Plummer, L. N. and Busenberg, E.: The solubilities of calcite, aragonite and vaterite in $\mathrm{CO}_{2}-\mathrm{H}_{2} \mathrm{O}$ solutions between 0 and $90^{\circ} \mathrm{C}$, and an evaluation of the aqueous model for the system $\mathrm{CaCO}_{3}$ $\mathrm{CO}_{2}-\mathrm{H}_{2} \mathrm{O}$, Geochim. Cosmochim. Ac., 46, 1011-1040, 1982.

Popovska, C. and Bonacci, O.: Basic data on the hydrology of Lakes Ohrid and Prespa, Hydrol. Process, 21, 658-664, doi:10.1002/hyp.6252, 2007.

Popov, V., Anovska, E., Arsov, M., Amataj, S., Kolaneci, M., Stamos, A., Arsov, L., Anovski, T., Kiri, E., and Gelaj, A.: Study of the Prespa-Ohrid lake system using tracer experiments and the lake's water balance, 5th International Conference on Sustainable Water Resources Management, Malta, 9-11 September 2009, Water Resour. Manag., V, Book Series: WIT Transactions on Ecology and the Environment, 125, 75-84, 2009.

Raidt, H. and Koschel, R.: Variable morphology of calcite crystals in hardwater lakes, Limnologica, 23(1), 85-89, 1993.

Reimer, P. J., Baillie, M. G. L., Bard, E., Bayliss, A., Beck, J. W., Blackwell, P. G., Bronk Ramsey, C., Buck, C. E., Burr, G. S., Edwards, R. L., Friedrich, M., Grootes, P. M., Guilderson, T. P., Hajdas, I., Heaton, T. J., Hogg, A. G., Hughen, K. A., Kaiser,
K. F., Kromer, B., McCormac, F. G., Manning, S. W., Reimer, R. W., Richards, D. A., Southon, J. R., Talamo, S., Turney, C. S. M., van der Plicht, J., and Weyhenmeyer, C. E.: IntCal09 and Marine09 radiocarbon age calibration curves, 0-50,000 years cal BP. Radiocarbon, 51(4), 1111-1150, 2009.

Roelofs, A. K. and Kilham, P.: The diatom stratigraphy and paleoecology of Lake Ohrid, Yugoslavia, Palaeogeogr. Palaeocl., 42, 225-245, 1983.

Rothwell, R.: Minerals and Mineraloids in Marine Sediments: an Optical Identification Guide, Elsevier Applied Science, London, 279 pp., 1989.

Shapley, M. D., Ito, E., and Donovan, J. J.: Authigenic calcium carbonate flux in groundwater-controlled lakes: Implications for lacustrine paleoclimate records, Geochim. Cosmochim. Acta, 69(10), 2517-2533, 2005.

Stankovic, S.: The Balkan Lake Ohrid and its Living World, Faculty of Sciences, Monographia Biologicae, Vol. IX. Uitgeverij Dr. W. Junk, Den Haag, Netherlands, 357 pp., 1960.

Trajanovski, S., Albrecht, C., Schreiber, K., Schultheiß, R., Stadler, T., Benke, M., and Wilke, T.: Testing the spatial and temporal framework of speciation in an ancient lake species flock: the leech genus Dina (Hirudinea: Erpobdellidae) in Lake Ohrid, Biogeosciences, 7, 3387-3402, doi:10.5194/bg-7-3387-2010, 2010.

Vogel, H., Wessels, M., Albrecht, C., Stich, H.-B., and Wagner, B.: Spatial variability of recent sedimentation in Lake Ohrid (Albania/Macedonia), Biogeosciences, 7, 3333-3342, doi:10.5194/bg7-3333-2010, 2010a.

Vogel, H., Wagner, B., Zanchetta, G., Sulpizio, R., and Rosén, P.: A paleoclimate record with tephrochronological age control for the last glacial-interglacial cycle from Lake Ohrid, Albania and Macedonia, J. Paleolimnol., 44(1), 295-310, doi:10.1007/s10933-009-9404-x, 2010b.

Wagner, B., Lotter, A. F., Nowaczyk, N., Reed, J. M., Schwalb, A., Sulpizio, R., Valsecchi, V., Wessels, M., and Zanchetta, G.: A 40,000-year record of environmental change from ancient Lake Ohrid (Albania and Macedonia), J. Paleolimnol., 41(3), 407430, 2009.

Wagner, B., Vogel, H., Zanchetta, G., and Sulpizio, R.: Environmental change within the Balkan region during the past ca. $50 \mathrm{ka}$ recorded in the sediments from lakes Prespa and Ohrid, Biogeosciences, 7, 3187-3198, doi:10.5194/bg-7-3187-2010, 2010.

Wagner, B., Reicherter, K., Daut, G., Wessels, M., Matzinger, A., Schwalb, A., Spirkovski, Z., and Sanxhaku, M.: The potential of Lake Ohrid for long-term palaeoenvironmental reconstructions, Palaeogeogr. Palaeocl., 259, 341-356, doi:10.1016/j.palaeo.2007.10.015, 2008a.

Wagner, B., Sulpizio, R., Zanchetta, G., Wulf, S., Wessels, M., Daut, G., and Nowaczyk, N.: The last 40 ka tephrostratigraphic record of Lake Ohrid, Albania and Macedonia: a very distal archive for ash dispersal from Italian volcanoes, J. Volcanol. Geoth. Res., 177 (1), 71-80, 2008b.

Watzin, M. C., Puka, V., and Naumoski, T. B.: Lake Ohrid and its Watershed, State of the Environment Report. Lake Ohrid Conservation Project, Tirana, Albania and Ohrid, Macedonia, 134 pp., 2002. 